\title{
Neutrophils in Immunity
}

\author{
So-Youn Woo* \\ Departments of Microbiology, School of Medicine, Ewha Womans University, Seoul, Korea
}

\begin{abstract}
Neutrophils are the most abundant white blood cells in the peripheral blood and have long been recognized as the major phagocytes in acute infection by destroying extracellular pathogens. Although research on neutrophils hampered by intractability in the experiments, the newly discovered effector functions of neutrophils includes granular proteins, and cytokines, extracellular traps. With all effector mechanism neutrophils play a critical role in the pathogenesis of acute and chronic infection, autoimmunity and cancer.
\end{abstract}

Key Words: Inflammation, Antimicrobial, Granule, Neutrophil extracellular trap (NET)

호중구는 면역학의 발전 초기에 발견되어 그 기능에 대한 연구는 한 세기가 지난 지금까지 계속되고 있으며, 또한 Th17 림프구의 활성화 경로를 통한 면역반응의 매 개체로서 호중구의 역할이 잘 알려져 있다 (1). 본 글에 서는 호중구의 활성화 경로와 항미생물반응, 그리고 자 가면역질환과 암 질환에서의 호중구의 역할에 대해 정리 하여 편집자에게 전하고자 합니다.

호중구는 선천면역반응에 중요한 역할을 담당하고 있 으나, 후천면역반응에 대한 연구에 비해 호중구에 대한 연구는 비약적인 발전을 이루지 못하였다 (2). 그 주된 요 인 중 하나는 호중구가 실험하기 어려운 조건을 갖추고 있는 것으로, 세포의 수명이 짧고, 또한 완전히 분화한 세포로서 세포배양으로 증식유도가 어렵다는 단점이 있 다. 따라서 호중구에서는 분자생물학적인 실험방법인 전 달감염법과 RNA 간섭법 등을 사용한 기능 연구를 수행 하기 어렵기 때문에, 그 대신 호중구와 유사한 세포주를 사용한다. 이 세포주의 경우는 호중구의 복합적인 기능을 모두 대신하여 제시하기 어렵고, 무엇보다 배양용기에서 의 세포주로서는 조직에 존재하거나 순환하는 호중구의

Received: May 21, 2012/ Revised: May 25, 2012

Accepted: May 29, 2012

* Corresponding author: So-Youn Woo. \#207, Departments of Microbiology, School of Medicine, Ewha Womans University, Seoul, 158-701, Korea.

Phone: +82-2-2650-5737, Fax: +82-2-2653-8891

e-mail: soyounwoo@ewha.ac.kr
기능을 파악하기 어렵다. 즉, 세포주를 사용한 호중구의 기능 연구의 결과는 이러한 제한점을 고려하여 해석하 고 적용되어야 한다. 또한 마우스를 사용한 생체 내 실 험의 결과는 사람의 호중구와의 차이점을 반드시 고려 해야 하는데, 가장 큰 차이 중 하나는 항미생물작용의 범 위와 순환하는 호중구의 분획의 차이(마우스는 $30 \%$, 사 람은 $70 \%$ 차지)이다 (3).

호중구의 분화는 골수에서 이루어지며, 여기에서는 다 양한 사이토카인과 성장인자의 작용에 의해 조혈줄기세 포가 골수계세포로 분화하고, 이것은 과립구로의 분화 단 계를 거쳐 호중구로 최종 분화된다. 이와 같은 분화과정 을 거치는 동안 호중구와 그 전구세포들은 다양한 과립 단백을 발현하게 된다. 이들 과립은 성분에 따라 아주르 친화과립(azurophilic), 특이과립(specific), 젤라틴분해효소 (gelatinase)의 3 가지로 분류한다 (4). 이들 서로 다른 과립 의 발현은 분화 단계에 따라 서로 다른 전사인자의 영향 을 받아 생산된다 (5).

골수에서 만들어진 호중구는 건강한 사람의 경우 그 생산이 엄격하게 조절되는데, 순환계로 유입되는 호중구 의 수와 감염 시 유리되는 호중구의 보유량은 케모카인 의 자극에 의해 결정된다. 호중구는 체내에서 6 8시간 을 순환하는 것으로 알려져 있으며, 이것은 사람의 세포 중 가장 짧은 수명에 해당하는 것이다. 이러한 짧은 수명 을 갖는 이유는 잘 알려져 있지 않지만, 호중구의 세포사 
멸을 통해 조직에 손상을 줄 수 있는 과립단백의 유출을 차단할 수 있다는 보고가 있어, 완전한 기능의 호중구를 확보하기 위한 것으로 생각할 수 있다 (3).

호중구의 다양한 과립단백은 숙주조직뿐 아니라 외부 항원의 손상을 유발하여 미생물의 침입을 제거할 수 있 다. 호중구가 비활성화 상태에서 외부항원을 제거할 수 있는 활성화 상태로 변화하기 위해서는 호중구가 화학주 성의 농도구배를 인식하고, 액틴의 재배열이 일어나 세포 의 모양과 운동성의 변화가 생겨 혈관내피세포를 통과 하는 일련의 과정을 거치게 된다. 감염부위에 도착한 호 중구는 탈과립을 통해 항미생물작용을 일으켜 외부의 미 생물항원을 처치한다.

\section{호중구의 활성화}

염증이 개시되면, 세균 혹은 숙주유래의 염증신호가 많 아지며, 이것은 염증부위 근처의 혈관내피세포를 자극한 다. 대표적인 것으로는 그람음성세균의 lipopolysaccharide (LPS), fMLP, 화학주성인자, 종양괴사인자(TNF- $\alpha$ ), 인터 루킨 $1 \beta, \mathrm{IL}-17$ 등으로 혈관내피세포를 자극하여 P-selectin, E-selectin, ICAM과 같은 인테그린의 발현이 증가한다 (4). 혈관 속을 순환하는 동안 호중구는 혈관내피세포와 끊 임없이 접촉하며 염증의 결과로 활성화된 혈관내피세포 를 찾아간다. 이 때 모세관 이후 세정맥과 같이 혈류의 흐름이 변하고 폭이 좁아진 구역에서 활성화된 혈관내피 세포와 마주칠 확률이 높다 $(6,7)$. 호중구의 표면에 발 현된 P-selectin glycoprotein ligand-1 (PSGL-1)과 L-selectin 을 통해 활성화된 혈관내피세포의 P-selectin, E-selectin 과 결합하여 혈관벽에 호중구가 매달려 굴러가는 형태가 되며 $(8,9)$, 이 단계에서 Src kinase, syk, phosphoinositide 3-kinase (PI3K), p38의 활성화를 통해 호중구의 항미생물 기전이 활성화되기 시작하며 (10) 다음 단계인 $\beta 2$ 인테 그린(LFA-1, Mac-1)의 활성화를 통한 혈관세포와의 결합 이 이루어지고 (11) 혈관내피세포를 통과하는 호중구의 이동이 일어난다 (12). 인테그린의 결합과 함께 화학주성 인자와 사이토카인의 자극으로 호중구의 모양이 변해 케 모카인 수용체와 탐식수용체가 집중된 선두의 위족구조 물이 나타나며, 화학주성인자의 농도에 따라 호중구가 이동하는 동시에 호흡터짐(활성화)이 시작된다. 혈관내피 세포 아래의 기저막은 라미닌과 제 4 형 콜라겐으로 이루 어진 망사 같은 구조로 호중구의 탈과립을 통해 유리된
효소가 기저막을 용해함으로써 호중구가 통과하는 것으 로 생각된다. 이제 조직으로 들어온 호중구는 외부항원과 숙주유래의 다양한 고농도의 염증물질, 대표적으로 숙 주의 IL-8이나 세균의 fMLP에 노출되어 화학주성을 나 타낸다. 이때 관여하는 케모카인 수용체와 FPR1(fMLP 수용체) 수용체는 G 단백결합 단백질로 MAPK/ERK 신 호전달경로를 활성화하고, 산화적 호흡터짐이 시작된다. 또한 FRP1의 활성화는 ATP의 유리를 촉진하고 (13), 외 부항원의 분자구조를 인식하는 고유한 패턴인식수용체 (대표적으로 Toll 유사 수용체, TLR)를 통해서도 호중구 의 활성화가 일어난다. 호중구는 TLR3를 제외한 TLR4, TLR2, TLR5, TLR9을 발현하고 있다 (14). 호중구가 최고 의 화학주성인자의 농도구역에 다다르게 되면, 호중구는 이동을 멈추고 탈과립이 일어나 항미생물성분을 유리한 다. 이때는 호중구의 항미생물작용이 최고조에 다다른 때이다.

호중구에 작용하는 화학주성인자나 패턴인식수용체의 자극은 다양하기 때문에, 각각의 구성성분은 호중구에 대 한 priming, 탈감작, 신호전달 등의 작용을 한다. 즉, 한 종류의 자극은 호중구의 활성화에 미미한 영향을 끼치지 만, 다음 신호에 대한 반응을 증폭할 수 있으며, 그 예로 LPS는 호중구의 NADPH 산화효소의 복합체를 모이게 하 고, 그 이후의 fMLP 자극에 의해 호흡터짐이 일어나게 한다 (15). 탈감작은 케모카인의 경우 자극 이후에 수용 체의 endocytosis가 일어나 수용체를 통한 자극의 전달이 감소하게 되는 것이 한 예이다 (16). IL-8의 경우는 농도 에 따라 호중구에 미치는 영향이 다른 것으로 나타났는 데, 저 농도에서는 L-selectin이 감소하고 $\beta 2$ 인테그린의 발현이 증가하였으며, 다음 단계의 농도에서는 호흡터짐 이, 이 후의 고농도에서는 탈과립이 관찰되었다 (17).

\section{호중구의 항미생물작용}

호중구의 항미생물작용은 탐식작용과 탈과립, NETosis (neutrophil extracellular trap)를 통해 일어난다. 호중구는 조직에 손상을 입힐 수 있는 효소를 지니고 혈관 속을 순환해야 하기 때문에, 특별한 저장장치를 지니고 있으며 이것이 바로 과립구조이다. 호중구과립은 크게 3 가지로 분류하며, 첫째는 아주르친화과립(peroxidase 양성 혹은 일차과립)이라고도 한다. 이것은 호중구과립 중 가장 크 며 $(0.3 \mu \mathrm{m})$ 호중구의 발생과정에서 가장 먼저 생성되어 
관찰되는 과립이다. 아주르친화과립이라는 이름이 붙게 된 것은 염기성 염료인 azure A에 염색되기 때문이며, 이 것은 호흡터짐에 중요한 myeloperoxidase (MPO)를 포함 한다 (18). 그 외에도 defensing, lysozyme, bactericidal/ permeability-increasing protein (BPI), serine protease (elastase, proteinase 3, cathepsin G) 등을 갖는다. 둘째는 특이과립(이 차과립)으로 호중구의 분화과정에서 일차과립형성 이후에 만들어진다. 이것은 $0.1 \mu \mathrm{m}$ 로 크기가 작고, $\mathrm{MPO}$ 를 포함 하지 않고 lactoferrin을 포함하고 있다. 그 외에도 NGAL, hCAP-18, lysozyme 등을 포함한다 (18). 셋째는 gelatinase (삼차과립)으로 크기는 이차과립보다 작고, gelatinase와 leukolysin의 저장소가 되며 $\mathrm{MPO}$ 는 포함하지 않는다. 이 것은 호중구의 분화과정에서 가장 나중에 형성된다 (4). 네 번째 구조물은 분비소포(secretory vesicle)로 이것 역시 호중구의 과립의 한 형태로 분류되지만, 이것은 골지체에 서 나오는 것이 아니고, 호중구의 분화 마지막 단계에서 세포 내 섭취경로를 통해 형성되는 구조물로서 내용물 은 혈장단백인 알부민 등이 포함된다 (19). 이 소포는 호 중구의 이동 시 세포막에 발현하는 중요한 분자의 저장 소가 된다.

또한 호중구가 정확히 염증부위로 이동하여 탈과립이 일어나는데, 염증자극에 대한 탈과립의 정도는 아주르친 화과립이 가장 어렵고, 그 다음으로 특이과립, gelatinase (삼차과립), 분비소포의 차례이다 (20). 즉 호중구가 혈관 내피세포에 결합한 후 셀렉틴과 케모카인의 자극에 의해 분비소포가 유리된다. 그 결과 $\beta 2$ 인테그린, 보체 수용체, $\mathrm{Fc} \gamma \mathrm{RIII}$ 수용체 $(\mathrm{CD} 16)$ 의 발현되면 견고한 결합이 일어나 삼차과립이 분비되어 호중구가 기저막을 뜷고 진행한다. 염증부위에서는 아주르친화과립과 2차과립 모두가 분비 되며 이것은 또한 탐식소포와 융합되어 항미생물작용을 나타내고 NADPH 효소의 활성화를 유도한다.

이러한 과립에서 유리한 단백효소는 항미생물효과 이 외에도 다른 면역세포에 신호전달의 자극으로 전달되어 proteinase 3 이나 azurocidin의 경우는 단핵구의 모집을 유 도하고 탐식기능을 항진시킨다.

\section{Neutrophil extracellular trap}

활성화된 호중구는 NETosis가 일어난다. 이것은 능동적 인 세포사멸의 형태로 뭉친 염색질이 세포외 공간으로 방출되는 것이다 (21). 이러한 섬유모양의 엉긴 구조물을 neutrophil extracellular trap (NET)이라고 하며 여기에는 히 스톤과 항미생물성분이 과립상태와 세포질 단백으로 존 재하게 된다. NET 구조는 다양한 종류의 미생물에 대해 항미생물작용을 나타내는 것으로 알려졌는데, 이것은 고 농도의 항미생물성분이 노출되어 미생물을 죽이는 것으 로 보인다 (22).

이러한 NET의 형성 기전에 대해서는 아직 잘 알려 져 있지 않다. 다만, $\mathrm{NADPH}$ 산화효소와 $\mathrm{MPO}$ 가 필요하 다는 결과 등에 의해 활성산소종의 형성경로가 이러한 $\mathrm{NET}$ 를 만드는 것으로 이해하고 있다. 또한 NADPH 산 화효소의 상위 신호전달경로에 있는 Raf-MEK-ERK 경 로가 NET 형성에 관여하는 것으로 알려졌다 (23). 그 외 에도 neutrophil elastase, autophagy 등이 NET 형성에 관계 하는 것으로 보고되었다 (24).

이러한 NET 형성 기전에 대한 연구는 모두 생체 외 실험을 통해 보고된 것이나, NET가 일어나지 않는 녹아 웃 동물모델을 만들기는 어려우며, 특히 NET 형성에 중 요한 DNA와 히스톤단백을 제외하고는 감염모델을 사 용하기 어렵다는 단점이 있다. 즉, NET의 형성이 항미 생물작용을 나타낸다는 증거로 간접적인 것이긴 하지만, DNase가 세균의 독력인자가 되어 숙주 내에서 세균이 더 효과적으로 증식한다는 것과 chronic granulomatous disease 환자에서 NADPH 효소에 대한 유전자치료 후 호중구의 탐식기능은 완전히 회복되지 않았으나 NET 형 성이 일어나고 그 후에 Aspergillus에 대한 지속감염이 사라진 것이 좋은 예이다 (25).

이러한 NET의 형성은 다량의 병원균이 침입하여 즉시 탐식작용이 일어나지 못할 때 매우 유용할 것으로 생각 되지만, 반면 NET에 의한 숙주의 손상 기전도 존재한다. 즉, $\mathrm{NET}$ 에 대해 자가분자가 세포외기질과 결합하여 노 출되면, 자가면역반응을 유도할 수 있다. 따라서 NET는 전신성홍반성낭창(SLE)과 같은 자가면역질환의 발생과 관련이 있으며 (26), 패혈증에 의한 혈소판 유도의 NET 에 의해서는 조직 손상을 동반한 간독성이 나타나기도 한다 (27). 혈소판 자체가 NET 구조에 결합하기도 하며, 이러한 경우 심부정맥혈전증 등이 일어날 수 있다 (28). 낭성섬유증환자의 호흡기에서 NET가 관찰되기도 하며, 이것이 객담의 점도를 증가시키고 폐기능을 감소시킨다 는 보고도 있다 (29).

따라서 NET의 형성과 소멸 시기가 제때 이루어져야 조직의 항상성을 유지할 수 있다. 사람의 혈장에는 
nuclease DNase I이 포함되어 있는데, 가족형 SLE의 경우 DNase I의 유전자 변형이 관여하는 것이 보고되었다 (30).

\section{호중구와 암}

악성종양과 염증과의 관계는 1863년 Rudolf Virchow가 기술하였으며, 그 이후에 호중구에 의한 $\operatorname{ROS}$ 형성이 산 화스트레스를 통해 유전자의 손상을 유도하고 이것이 종 양발생의 원인이 된다는 실험결과가 있다. 이 결과는 생 체 내에서 증명되지는 않았으나, 호중구는 종양의 진행에 영향을 미치는 것으로 알려져 있다. 즉, 일부 종양에서는 IL-8을 분비하여 호중구를 유입하고 (31), 그 결과 혈관증 식 (32)과 종양의 전이 (33), 면역반응의 억제 (34) 등이 일어난다. 그 외에 myeloid-derived suppressor cell (MDSC) 로 명명된 미성숙한 골수계세포는 종양이나, 자가면역질 환, 감염증에서 과립구 등이 완전히 분화가 이루어지지 않아 미성숙한 상태로 존재하면서 $\mathrm{T}$ 림프구의 면역반응 을 억제하는 기능을 수행한다 (35). 이들 MDSC는 단핵 구와 과립구계열이 섞여 있으나, 호중구와도 유사한 표 현형을 갖는데 마우스의 경우 호중구 마커에 해당하는 $\mathrm{CD} 11 \mathrm{~b}+\mathrm{Gr}-1+$ 를 나타낸다. 사람의 신장암에서 $\mathrm{MDSC}$ 는 활성화된 호중구와 유사한 표현형을 보였고, arginase와 $\mathrm{NOS}$ 활성화를 통해 $\mathrm{T}$ 림프구의 증식을 억제할 뿐 아니 라 ROS의 형성을 통해 $\mathrm{T}$ 림프구의 기능을 억제한다고 보고되었다 (36).

종합해 보면 호중구는 염증반응에 주요한 역할을 하는 탐식세포로서, 외부항원을 소멸하는 항미생물작용 외에도 선천면역반응과 후천면역반응을 연결하며, 또한 자가면 역질환과 만성염증, 혹은 종양의 증식을 유도하기도 한 다. 호중구의 계속적인 연구과제로는 짧은 수명과 관련 한 세포의 사멸기전, 활성산소종 의존적인 신호전달기전 을 밝히는 것 등이 필요하다.

\section{참 고 문 헌}

1) Cua DJ, Tato CM. Innate IL-17-producing cells: the sentinels of the immune system. Nat Rev Immunol 2010;10:479-89.

2) Nathan C. Neutrophils and immunity: challenges and opportunities. Nat Rev Immunol 2006;6:173-82.

3) Amulic B, Cazalet C, Hayes GL, Metzler KD, Zychlinsky A. Neutrophil function: from mechanisms to disease. Annu Rev
Immunol 2012;30:459-89.

4) Borregaard N. Neutrophils, from marrow to microbes. Immunity 2010;33:657-70.

5) Borregaard N, Cowland JB. Granules of the human neutrophilic polymorphonuclear leukocyte. Blood 1997;89:3503-21.

6) Lawrence MB, Kansas GS, Kunkel EJ, Ley K. Threshold levels of fluid shear promote leukocyte adhesion through selectins (CD62L, P, E). J Cell Biol 1997;136:717-27.

7) Finger EB, Puri KD, Alon R, Lawrence MB, von Andrian UH, Springer TA. Adhesion through L-selectin requires a threshold hydrodynamic shear. Nature 1996;379:266-9.

8) Kansas GS. Selectins and their ligands: current concepts and controversies. Blood 1996;88:3259-87.

9) McEver RP, Cummings RD. Role of PSGL-1 binding to selectins in leukocyte recruitment. J Clin Invest 1997;100:S97 -103 .

10) Yago T, Shao B, Miner JJ, Yao L, Klopocki AG, Maeda K, et al. E-selectin engages PSGL-1 and CD44 through a common signaling pathway to induce integrin alphaLbeta2-mediated slow leukocyte rolling. Blood 2010;116:485-94.

11) Campbell JJ, Hedrick J, Zlotnik A, Siani MA, Thompson DA, Butcher EC. Chemokines and the arrest of lymphocytes rolling under flow conditions. Science 1998;279:381-4.

12) Constantin G, Majeed M, Giagulli C, Piccio L, Kim JY, Butcher $\mathrm{EC}$, et al. Chemokines trigger immediate beta2 integrin affinity and mobility changes: differential regulation and roles in lymphocyte arrest under flow. Immunity 2000;13:759-69.

13) Chen Y, Yao Y, Sumi Y, Li A, To UK, Elkhal A, et al. Purinergic signaling: a fundamental mechanism in neutrophil activation. Sci Signal 2010;3:ra45.

14) Sabroe I, Dower SK, Whyte MK. The role of Toll-like receptors in the regulation of neutrophil migration, activation, and apoptosis. Clin Infect Dis 2005;41:S421-6.

15) Guthrie LA, McPhail LC, Henson PM, Johnston RB Jr. Priming of neutrophils for enhanced release of oxygen metabolites by bacterial lipopolysaccharide. Evidence for increased activity of the superoxide-producing enzyme. J Exp Med 1984;160: 1656-71.

16) Didsbury JR, Uhing RJ, Tomhave E, Gerard C, Gerard N, Snyderman R. Receptor class desensitization of leukocyte chemoattractant receptors. Proc Natl Acad Sci U S A 1991;88: 11564-8.

17) Ley K. Integration of inflammatory signals by rolling neutro- 
phils. Immunol Rev 2002;186:8-18.

18) Lacy P. The role of Rho GTPases and SNAREs in mediator release from granulocytes. Pharmacol Ther 2005;107:358-76.

19) Borregaard N, Sørensen OE, Theilgaard-Mönch K. Neutrophil granules: a library of innate immunity proteins. Trends Immunol 2007;28:340-5.

20) Kjeldsen L, Bainton DF, Sengeløv H, Borregaard N. Structural and functional heterogeneity among peroxidase-negative granules in human neutrophils: identification of a distinct gelatinase-containing granule subset by combined immunocytochemistry and subcellular fractionation. Blood 1993;82: 3183-91.

21) Brinkmann V, Reichard U, Goosmann C, Fauler B, Uhlemann $\mathrm{Y}$, Weiss DS, et al. Neutrophil extracellular traps kill bacteria. Science 2004;303:1532-5.

22) Papayannopoulos V, Zychlinsky A. NETs: a new strategy for using old weapons. Trends Immunol 2009;30:513-21.

23) Hakkim A, Fuchs TA, Martinez NE, Hess S, Prinz H, Zychlinsky A, et al. Activation of the Raf-MEK-ERK pathway is required for neutrophil extracellular trap formation. Nat Chem Biol 2011;7:75-7.

24) Remijsen Q, Vanden Berghe T, Wirawan E, Asselbergh B, Parthoens E, De Rycke R, et al. Neutrophil extracellular trap cell death requires both autophagy and superoxide generation. Cell Res 2011;21:290-304.

25) Bianchi M, Hakkim A, Brinkmann V, Siler U, Seger RA, Zychlinsky A, et al. Restoration of NET formation by gene therapy in CGD controls aspergillosis. Blood 2009;114:2619 $-22$.

26) Hakkim A, Fürnrohr BG, Amann K, Laube B, Abed UA, Brinkmann $\mathrm{V}$, et al. Impairment of neutrophil extracellular trap degradation is associated with lupus nephritis. Proc Natl Acad Sci U S A 2010;107:9813-8.

27) Clark SR, Ma AC, Tavener SA, McDonald B, Goodarzi Z, Kelly MM, et al. Platelet TLR4 activates neutrophil extra- cellular traps to ensnare bacteria in septic blood. Nat Med 2007;13:463-9.

28) Fuchs TA, Brill A, Duerschmied D, Schatzberg D, Monestier M, Myers DD Jr, et al. Extracellular DNA traps promote thrombosis. Proc Natl Acad Sci U S A 2010;107:15880-5.

29) Marcos V, Zhou Z, Yildirim AO, Bohla A, Hector A, Vitkov L, et al. CXCR2 mediates NADPH oxidase-independent neutrophil extracellular trap formation in cystic fibrosis airway inflammation. Nat Med 2010;16:1018-23.

30) Yasutomo K, Horiuchi T, Kagami S, Tsukamoto H, Hashimura $\mathrm{C}$, Urushihara M, et al. Mutation of DNASE1 in people with systemic lupus erythematosus. Nat Genet 2001;28:313-4.

31) Ji H, Houghton AM, Mariani TJ, Perera S, Kim CB, Padera R, et al. K-ras activation generates an inflammatory response in lung tumors. Oncogene 2006;25:2105-12.

32) Shojaei F, Singh M, Thompson JD, Ferrara N. Role of Bv8 in neutrophil-dependent angiogenesis in a transgenic model of cancer progression. Proc Natl Acad Sci U S A 2008;105:2640 -5 .

33) Huh SJ, Liang S, Sharma A, Dong C, Robertson GP. Transiently entrapped circulating tumor cells interact with neutrophils to facilitate lung metastasis development. Cancer Res 2010;70: 6071-82.

34) Schmielau J, Finn OJ. Activated granulocytes and granulocytederived hydrogen peroxide are the underlying mechanism of suppression of t-cell function in advanced cancer patients. Cancer Res 2001;61:4756-60.

35) Gabrilovich DI, Nagaraj S. Myeloid-derived suppressor cells as regulators of the immune system. Nat Rev Immunol 2009; 9:162-74.

36) Rodriguez PC, Ernstoff MS, Hernandez C, Atkins M, Zabaleta $\mathrm{J}$, Sierra $\mathrm{R}$, et al. Arginase I-producing myeloid-derived suppressor cells in renal cell carcinoma are a subpopulation of activated granulocytes. Cancer Res 2009;69:1553-60. 